JURNAL ILMIAH KORPUS
Vol. 5 No. 3, 2021
ISSN (online): 2614-6614
Available online at https://ejournal.unib.ac.id/index.php/korpus/index
doi: https://doi.org/10.33369/jik.v5i3.19165

\title{
PENGINTEGRASIAN BUDAYA LOKAL BESEMAH KEDALAM MATERI SASTRA DI STKIP MUHAMMADIYAH PAGARALAM
}

\author{
${ }^{1}$ Tri Rohani; ${ }^{2}$ Yoga Pratama \\ ${ }^{1}$ STKIP Mubammadiyah Pagaralam; ${ }^{2}$ STKIP Mubammadiyah Pagaralam \\ Korespondensi: liehans33@gmail.com; vogaxiaomiss24@gmail.com
}

Abstrak

Penelitian ini adalah penelitian pengembangan atau Research \& Development yang bertujuan untuk mengembangkan materi pembelajaran berbasis kearifan lokal. Pengembangan materi didasarkan pada hasil kuisioner analisa kebutuhan mahasiswa dan dosen di STKIP Muhammadiyah pada mata kuliah Introduction to Literature yang divalidasi ahli. Data penelitian dikumpulkan melalui kuisioner, wawancara dan validasi ahli. Berdasarkan data analisa kebutuhan mahasiswa yang disebar kepada 35 mahasiswa, ditemukan bahwa rata-rata mahasiswa menyatakan bahwa mereka menyukai sastra atau literature, namun mengalami kendala seperti, bahasa teks, teks yang tidak familiar, teks yang susah diapresiasi dan kurang memiliki keamampuan dalam menulis teks. Akan tetapi, menurut mereka kearifan lokal sangat penting untuk dijadikan bahan ajar selain untuk melestarikan dan menambah ilmu pengetahuan tentang seni dan budaya lokal setempat juga untuk menambah pemahaman mahasiswa dalam memahami bahan ajar yang digunakan. Selain itu, mahasiswa membutuhkan bahan ajar yang berukuran lebih bersar dan memiliki lembar kerja yang lebih banyak. Hal ini selaras dengan hasil wawancara dosen yang dideskripsikan secara kualitatif yang menjelaskan bahwa kearifan lokal bisa menjadi alternative pengajaran yang baik untuk membantu mahasiswa lebih memahami materi yang ada pada teks sehingga dapat membantu kesulitan-kesulitan yang dihadapi mahasiswa. Berdasarkan hasil validasi ahli materi kearifan lokal juga menjadi nilai lebih pada materi sastra yang dikembangkan. Hasil validasi ahli menjelaskan bahwa dari keseluruhan aspek validasi, pengembangan materi sastra yang dilakukan sudah memenuhi kriteria sangat baik dan memenuhi kebutuhan mahasiswa.

Abstract

This research is a Research \& Development which aims at investigating the development of instructional materials based on local wisdom. The materials developed were designed from the result of the students' need analysis and teacher specialist' interview at STKIP Muhammadiyah Pagaralam in Introduction to Literature subject and validated by experts. The research data were collected from student's questionnaire, specialist's interview and experts' validation. Regarding the data of the students' questionnaire which consisted of 35 students, it was found that most of the students were interested in literature but they found problems such as; the language of the texts, unfamiliar literary texts, difficult in appreciating the texts and lack of skill in writing literary text. However, according to them local wisdom was very important to be developed beside to preserve and enrich students' knowledge about the culture of the local area also to help students comprehend the materials as well. Besides, students also needed bigger text and more work sheets in the modul. This finding was also in line with the lecturer specialist's interview which was described qualitatively in which it explained that local wisdom can be such a good alternative literary material in teaching learning process to help students comprehend the 
texts used. Based on expert validation, local wisdom materials also gave an extra point in the materials developed. Expert validation stated that from the whole aspects of validation, the development of the materials met very good criteria and met the students' need.

Keywords: development, local wisdom, literary material, questionnaire, validation

\section{PENDAHULUAN}

Membaca teks-teks sastra dengan pemahaman yang kurang terhadap topik yang disajikan dapat menimbulkan beberapa kesulitan bagi sebagian mahasiswa. Diantara masalah-masalah yang dapat timbul adalah; tidak memahami isi bacaan, kosakata yang kurang familiar, dan tidak memiliki latar belakang pengetahuan tentang topik bacaan.

Karya sastra seperti kumpulan puisi, novel, cerita pendek atau drama sebaiknya digunakan dalam pengajaran bahasa asing karena karya sastra seperti ini memiliki semua fitur yang dibutuhkan untuk mengajar bahasa asing (Erdem, 2016). Hal ini selaras dengan pernyataan (Bao, 2016; Tomlinson, 2012; Mckay, 2003).

If the students are given unfamiliar topic to be discussed, they are most likely to give up and take time to do so. If the topic is familiar for them, they will be easy to comprehend the materials and the learning will take place. They have background knowledge about the topic and know what they are going to discuss. They will engage actively with the lesson.

Dengan kata lain dapat diartikan bahwa jika siswa diberikan materi yang tidak familiar mereka akan menyerah atau membutuhkan waktu untuk mempelajarinya akan tetapi, jika topik yang diberikan familiar, mereka akan lebih mudah memahami materi tersebut dan proses belajar mengajar dapat berjalan. Hal ini karena siswa memiliki latar belakang pengetahuan tentang topik dan mengetahui apa yang mereka akan diskusikan. Di sini siswa dapat terlibat secara aktif dalam pembelajaran.

Karena tidak adanya teks-teks yang mendukung latar belakang pengetahuan budaya mahasiswa, dianggap perlu dan penting untuk mengembangkan materi-materi sastra yang relevan dengan materi yang dipelajari dan mudah dipahami serta berlatar belakang sama dengan budaya yang dimiliki para mahasiswa. Hal ini merupakan salah satu cara untuk membantu para mahasiswa lebih memahami dan antusias dalam belajar sastra karena budaya lokal yang dikembangkan dapat menjadi referensi untuk menambah pemahaman para mahasiswa terhadap teks yang digunakan.

Pemakaian budaya lokal (etnis) dalam Pembelajaran Berbasis Budaya sangat bermanfaat bagi pemaknaan proses dan hasil belajar, karena peserta didik mendapatkan pengalaman belajar yang kontekstual (titian kambing) dan bahan apersepsi untuk memahami konsep ilmu pengetahuan dalam budayalokal (etnis) yang dimiliki. Disamping itu, model pengintegrasian budaya dalam pembelajaran dapat memperkaya budaya local (etnis) tersebut yang pada gilirannya juga dapat mengembangkan dan mengukuhkan budaya nasional yang merupakan puncak puncak budaya local dan budaya etnis yang berkembang (Dikti, 2004: 4). Lebih khusus, dalam penelitian ini adapun pengembangan yang dilakukan adalah pengintegrasikan budaya lokal setempat kedalam materi sastra yang didasarkan pada hasil kuisioner mahasiswa dan wawancara dosen dengan model pengembangan ADDIE.

\section{METODE}

Penelitian ini adalah penelitian pengembangan dengan model pengembangan ADDIE. ADDIE merupakan singkatan dari Analysis, Design, Development or Production, Implementatio or Delivery and Evaluations. Model ADDIE dikembangkan oleh Dick and Carry pada tahun 1996. Menurut (Barokati \& Annas, 2013) model ADDIE adalah 
model pengembangan yang menjadi salah satu pedoman pengembangkan pembelajaran yang efektif, dinamis dan mendukung pembelajaran itu sendiri. Model ADDIE merupakan salah satu model desain pembelajaran sistematik, model ini dikembangkan atau tersusun secara terprogram dengan urutan-urutan kegiatan yang sistematis dalam upaya pemecahan masalah belajar yang berkaitan dengan sumber belajar yang sesuai dengan kebutuhan dan karakteristik siswa. Model ADDIE dapat digunakan untuk berbagai macam model, strategi pembelajaran, media dan bahan ajar (Tegeh \& Kirna, 2013).

Menurut (Sugiyono, 2015: 38) model ADDIE ini terdiri dari 5 tahapan, yaitu Analyze (Analisis), Design (Perancangan), Development (Pengembangan), Implementation (Implementasi), dan Evaluation (Evaluasi). Dalam penelitian ini tahapan yang dilakuan hanya terbatas pada tahap Analisis, Perancangan dan Pengembangan. Pada tahap analisis, hal yang dilakukan yaitu menganalisis kebutuhan mahasiswa dan dosen dan permasalahan berupa materi yang relevan, buku yang digunakan, dan kondisi belajar mahasiswa. Pada tahap desain, dilakukan beberapa kegiatan antara lain merumuskan tujuan pembelajaran, menentukan materi atau pokok bahasan yang akan dipelajari, selanjutnya penyusunan bahan ajar dengan sistematika yang telah disesuaikan dengan kebutuhan siswa dan pada tahapan perancangan, peneliti menyiapan dan menulis materi pada buku ajar yang disesuaikan dengan kebutuhan siswa dalam melakukan kegiatan belajar.

Teknik pengumpulan data yang digunakan dalam penelitian ini adalah teknik kuisioner dan interview. Kuisioner dalam hal ini adalah kuisioner yang disebar kepada mahasiswa yang bertujuan untuk mengetahui analisa kebutuhan mahasiswa terhadap kebutuhan pengembangan bahan ajar. Kuisioner ini terdiri dari 10 pertanyaan pilihan ganda dengan 4 (pilihan) jawaban dan 5 pertanyaan uraian. Sedangkan interview dalam hal ini ditujukan kepada dosen pengampuh mata kuliah dalam bentuk uraian guna mengetahui situasi kelas dan kesulitan dalam proses belajar mengajar.

Analisa data kuisioner yang diberikan kepada mahasiswa dan dosen diolah secara objektif dan kemudian dideskripsikan. Adapun langkah-langkah analisis data kuisioner mahasiswa dan wawancara dosen adalah sebagai berikut: (1) data angket diperiksa dan diklasifikasikan secara objektif, (2) data angket dianalisis, (3) data angket dideskripsikan, dan (4) data angket disimpulan. Sedangkan untuk wawancara dosen, hasil wawancara dianalisa dan didiskripsikan dan kemudian disimpulkan secara kualitatif. Setelah diperoleh hasil, pengembangan bahan ajar dilakukan dengan mempertimbangkan hasil dari analisa data kuisioner mahasiswa dan wawancara dosen. Pengembangan dilakukan dengan memakai model pengembangan ADDIE's model. Dalam penelitian ini tahapan yang dilakukan hanya sampai tahapan pengembangan tanpa adanya tahap implementasi dan evaluasi.

Bahan ajar dikembangkan dalam 12 (dua belas) bab. Pada setiap bab, terdapat ringkasan, materi inti dan soal evaluasi. Bab-bab yang ada membahas tentang materi sastra yang disesuaikan dengan kebutuhan mahasiswa untuk lebih memahami materi utama dalam mata kuliah yang dipelajari. Bahan ajar juga disesuaikan dengan Rencana Pembelajaran Semester dari mata kuliah yang diampuh oleh dosen pengampuh. Setelah itu, bahan ajar ini dinilai oleh tim validasi ahli yang terdiri dari 3 (tiga) orang sebagai ahli kebahasaan dan ahli gerafik. Setelah dinilai, jika ada perbaikan, perbaikan dilakukan sesuai saran para ahli. 


\section{HASIL DAN PEMBAHASAN}

\section{Hasil}

1. Hasil Kuisioner Mahasiswa

Untuk mengetahui kebutuhan dan ketertarikan mahasiswa secara detail terhadap materi sastra yang disajikan, kuisioner diberikan dan dianalisa sebagai dasar pengembangan materi. Dengan memakai instrument penelitaian ini peneliti mendapat informasi tentang sikap, perspektif, dan atmospir kegiatan belajar mengajar di dalam kelas serta harapkan mahasiswa terhadap tercapainya tujuan pembelajaran khususnya pada materi sastra.

Kuisioner yang diberikan kepada mahasiswa berisi 10 (sepuluh) pertanyaan dengan pilihan a, b, c dan d, dan 5 (lima) pertanyaan dalam bentuk uraian. Kuisioner diberikan kepada mahasiswa semester IV. A dan IV. B yang mengambil mata kuliah Introduction to Literature, yang di dalamnya terdapat materi-materi sastra. Jumlah total keseluruhan mahasiswa adalah 35 orang. Semester IV. A berjumlah 20 orang dan semester IV. B berjumlah 15 orang.

Adapun formula yang digunakan untuk menghitung hasil dari kuisioner mahasiwa adalah, $\mathrm{P}(\%)=\frac{f \times 100}{N}$. Jawaban dari kuisioner didokumentasikan dan dianalisa untuk digunakan sebagai pertimbangan dalam mengembangkan materi.

Berdasarkan pengumpulan data dari kuisioner yang disebar, diperoleh hasil sebagai berikut:

Table 1. Data Kuisioner

\begin{tabular}{|c|c|c|c|c|}
\hline No. & Pertanyaan & $\begin{array}{l}\text { Frekuensi } \\
\text { (f) }\end{array}$ & Keterangan & $\begin{array}{l}\text { Persentase } \\
(\%)\end{array}$ \\
\hline 1. & $\begin{array}{l}\text { Menurut Anda, seberapa penting } \\
\text { pembelajaran Introduction to Literatur? }\end{array}$ & 18 & Penting & $51 \%$ \\
\hline 2. & $\begin{array}{l}\text { Apakah Anda menyukal } \\
\text { sastra/literature? }\end{array}$ & 31 & Menyukai & $89 \%$ \\
\hline 3. & $\begin{array}{l}\text { Bagaimana motivasi belajar Introduction } \\
\text { to Literature Anda? }\end{array}$ & 21 & Sedang & $60 \%$ \\
\hline 4. & $\begin{array}{l}\text { Kesulitan apa yang Anda alami dalam } \\
\text { pembelajaran Introduction to Literature? }\end{array}$ & 13 & $\begin{array}{l}\text { Sulit Menulis } \\
\text { Karya Sastra }\end{array}$ & $37 \%$ \\
\hline 5. & $\begin{array}{l}\text { Apakah pembelajaran Introduction to } \\
\text { Literature dapat Anda mengerti dengan } \\
\text { baik? }\end{array}$ & 28 & Baik & $80 \%$ \\
\hline 6. & $\begin{array}{l}\text { Apakah pembelajaran Introduction to } \\
\text { Literature dalam bahasa Inggris sulit } \\
\text { bagi Anda? }\end{array}$ & 22 & Sulit & $63 \%$ \\
\hline 7. & $\begin{array}{l}\text { Menurut Anda, } \\
\text { pemahaman Introduction to Literature } \\
\text { yang Anda miliki? }\end{array}$ & 21 & Cukup & $57 \%$ \\
\hline 8. & $\begin{array}{l}\text { Apakah modul pembelajaran } \\
\text { Introduction to Literature yang Anda } \\
\text { gunakan saat ini sudah memenuhi } \\
\text { kebutuhan Anda dalam memahami } \\
\text { sastra/literature? }\end{array}$ & 20 & Memenuhi & $60 \%$ \\
\hline 9. & $\begin{array}{l}\text { Menurut Anda, seberapa penting } \\
\text { kearifan lokal untuk dipelajari? }\end{array}$ & 23 & $\begin{array}{l}\text { Sangat } \\
\text { Penting }\end{array}$ & $66 \%$ \\
\hline 10. & $\begin{array}{l}\text { Apakah desain buku Introduction to } \\
\text { Literature yang Anda gunakan saat ini } \\
\text { cukup menarik? }\end{array}$ & 22 & Menarik & $63 \%$ \\
\hline
\end{tabular}


Untuk memperjelas temuan diatas, hasil kuisioner disajikan lebih ringkas dalam table berikut:

Table 2. Hasil Analisa Quisioner Mahasiswa

\begin{tabular}{cclc}
\hline No. & Pertanyaan $(\mathrm{Q})$ & \multicolumn{1}{c}{ Keterangan } & Persentase \\
\hline 1. & Q2 & Menyukai Sastra & $89 \%$ \\
2. & Q5 & $\begin{array}{l}\text { Mengerti Mata Kuliah Introduction to } \\
\text { Literature dengan Baik }\end{array}$ & $80 \%$ \\
3. & Q9 & $\begin{array}{l}\text { Pengintegrasian Kearifan Lokal } \\
\text { Sangat Penting }\end{array}$ & $66 \%$ \\
Desain Modul Introduction to & $63 \%$ \\
5. & Q10 & $\begin{array}{l}\text { Literarature Menarik } \\
\text { Pembelaaran Introduction to Literature }\end{array}$ & $63 \%$ \\
6. & Q6 & $\begin{array}{l}\text { Sulit } \\
\text { Motivasi Belajar Sastra Sedang }\end{array}$ & $60 \%$ \\
7. & Q8 & $\begin{array}{l}\text { Modul Introduction to Literature } \\
\text { Memenuhi Kebutuhan }\end{array}$ & $60 \%$ \\
9. & Q7 & $\begin{array}{l}\text { Pemahaman Tentang Sastra Cukup } \\
\text { Mata Kuliah Introduction to Literature }\end{array}$ & $57 \%$ \\
10. & Q1 & $\begin{array}{l}\text { Penting } \\
\text { Sulit Menulis Karya Sastra }\end{array}$ & $51 \%$ \\
\hline
\end{tabular}

Data di atas memperlihatkan bahwa 89\% mahasiswa menyukai pelajaran sastra, $80 \%$ menyatakan mengerti mata kuliah Introduction to Literature dengan baik, dan $66 \%$ mahasiswa menggangap pengintegrasian budaya lokal sangat penting. Selanjutnya, 63\% mahasiswa menyebutkan bahwa modul yang digunakan menarik namun sulit untuk dimengerti, kemudian 60\% mahasiswa menjawab memiliki motivasi sedang dan menyatakan bahwa modul yang dipakai memenuhi kebutuhan. Lebih lanjut, 57\% mahasiswa memiliki pemahaman yang cukup tentang sastra dalam hal ini sastra Indonesia, 51\% lainnya mengganngap mata kuliah Introduction to Literature penting akan tetapi 37\% dari mereka mengalami kesulitan dalam menulis teks sastra. Sedangkan dari soal uraian mahasiswa menghendaki modul yang berukuran lebih besar dan menginginkan lebar kerja yang lebih banyak.

\section{Hasil Wawancara Dosen}

Dari hasil wawancara dosen diperoleh informasi bahwa kendala yang dihadapi mahasiswa di kelas antara lain; mahasiswa memiliki motivasi sedang terhadap mata kuliah Introduction to Literature, kurang memahami istilah-istilah sastra, kurang familiar dengan karya sastra yang disajikan, sulit memahami teks karena dalam bahasa Inggris, dan sulit mengembangkan skill dalam menulis sebuah karya sastra. Dari segi modul yang digunakan, modul memiliki desain yang menarik, memiliki tujuan pembelajaran yang jelas, isi yang memadai namun dari segi ukuran perlu diperbesar dan lembar kerja perlu diperbanyak.

3. Hasil Validasi Ahli

Dari hasil validasi ahli didaptkan informasi sebagai berikut:

Table 3. Hasil Penilaian Validasi Abli

\begin{tabular}{cclc}
\hline No. & Aspek & \multicolumn{1}{c}{ Isi } & Nilai \\
\hline 1. & Desain Sampul & $\begin{array}{l}\text { Desain sampul menarik, } \\
\text { penggunaan huruf jelas, sesuai, } \\
\text { konsisten dan terbaca. }\end{array}$ & 13 \\
& &
\end{tabular}


2. Huruf, Ukuran Huruf, dan Pengetikan

Pemilihan huruf ketikan dan

3. Spas

4. Tata Letak

5. Penyajian Materi

6. Instruksi Pembelajaran

ukuran baik dan terbaca,

pengetikan baik, rapih dan

normal.

Spasi sesuai dan konsisten

Tata letak sesuai dan atraktif

bagi mahasiswa.

Materi disajikan dengan attraktif.

Penyajian materi dalam bab dan

latihan sesuai.

Materi disajikan secara

sistematis.

Instruksi pembelajaran jelas.

Instruksi sesuai.

Instruksi pembelajaran diurutkan

dengan sesuai.

7. Isi Topic sesuai dengan kebutuhan

mahasiswa.

Topic bermacam-macam dan dapat dimengerti oleh mahasiswa.

8. Bahasa

Bahasa yang digunakan sesuai dengan level mahasiswa.

Bahasa yang digunakan dapat

dimengerti oleh mahasiswa.

9. Materi Kearifan Lokal Materi yang disajikan sesuai dengan budaya setempat. Materi kearifan lokal beragam. Materi kearifan lokal memiliki hubungan dengan materi yang dipelajari.

10. Latihan Latihan sesuai dengan topik bahasan.

$\begin{array}{cc}\text { Total } & 136 / 10 \\ \text { Rata-rata } & 13,6\end{array}$

Dari hasil di atas, data dapat ditampilkan seperti table berikut.

\begin{tabular}{|c|c|c|c|}
\hline No. & Aspek & Isi & Nilai \\
\hline 1. & Materi Kearifan Lokal & $\begin{array}{l}\text { Materi yang disajikan sesuai } \\
\text { dengan budaya setempat. } \\
\text { Materi kearifan lokal beragam. } \\
\text { Materi kearifan lokal memiliki } \\
\text { hubungan dengan materi yang } \\
\text { dipelajari. }\end{array}$ & 15 \\
\hline 2. & $\begin{array}{l}\text { Huruf, Ukuran Huruf, } \\
\text { dan Pengetikan }\end{array}$ & $\begin{array}{l}\text { Pemilihan huruf ketikan dan } \\
\text { ukuran baik dan terbaca, } \\
\text { pengetikan baik, rapih dan } \\
\text { normal. }\end{array}$ & 15 \\
\hline 3. & Spasi & Spasi sesuai dan konsisten. & 15 \\
\hline 4. & Latihan & $\begin{array}{l}\text { Latihan sesuai dengan topik } \\
\text { bahasan. }\end{array}$ & 14 \\
\hline 5. & Desain Sampul & $\begin{array}{l}\text { Desain sampul menarik, } \\
\text { penggunaan huruf jelas, sesuai, } \\
\text { konsisten dan terbaca. }\end{array}$ & 13 \\
\hline 6. & Tata Letak & $\begin{array}{l}\text { Tata letak sesuai dan atraktif bagi } \\
\text { mahasiswa. }\end{array}$ & 13 \\
\hline 7. & Penyajian Materi & Materi disajikan dengan attraktif. & 13 \\
\hline
\end{tabular}




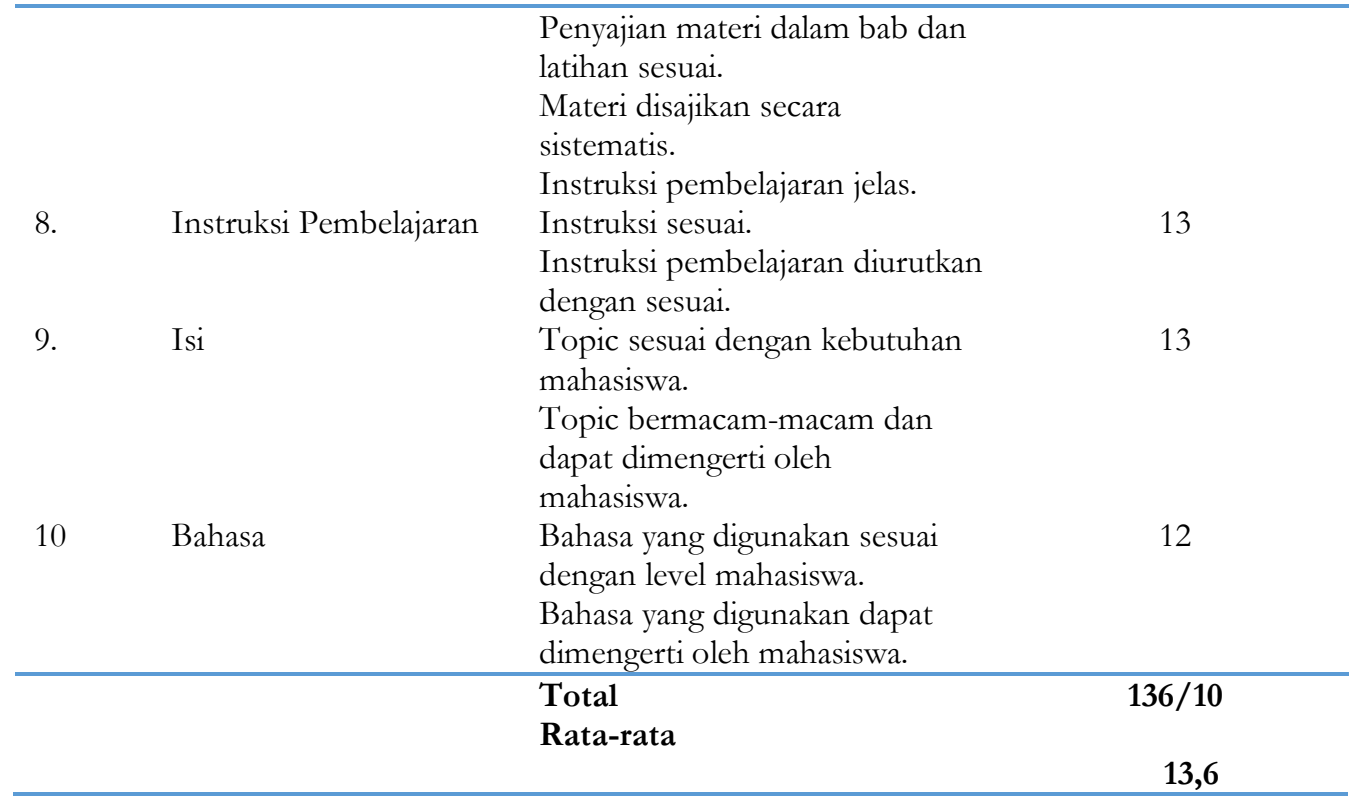

Table di atas menunjukan bahwa aspek materi kearifan lokal, huruf, ukuran huruf dan pengetikan, dan spasi mendapat nilai maksimal, yaitu 15 poin, aspek latihan atau evaluasi mendapat nilai 14 , desain sampul, tata letak, penyajian materi, instruksi pembelajaran dan isi masing-masing mendapat nilai 13 dan aspek bahasa mendapat nilai 12. Dari keseluruhan aspek rata-rata yang diperoleh adalah 13,6. Hal ini mengindikasikan bahwa pengembangan yang dilakukan sudah memenuhi kriteria umum suatu bahan ajar. Bahan ajar yang baik harus dapat menampung kebutuhan pengguna untuk membantu pengguna memahami materi inti dari suatu pembelajaran. Bahan ajar bukan sekedar buku pegangan guru atau siswa (kurikulum 2013) semata, tetapi bahan atau sumber belajar yang dapat digunakan dalam proses pembelajaran dengan tujuan memfasilitasi siswa atau membantu siswa memahami materi pokok atau konsep dari sumber belajar tersebut, dengan menyadarinya ke bahasa yang mudah dipahami siswa ( Noviarni: 2014)

\section{Pembahasan}

\section{Hasil Kuisioner Mahasiswa}

Dari hasil analisa kebutuhan mahasiswa dapat katakan bahwa dari kuisioner yang disebar kepada mahasiswa, ditemukan bahwa rata-rata mahasiswa menyatakan bahwa mereka menyukai sastra atau literature, mereka mengerti sastra dengan baik dan menurut pendapat mereka kearifan lokal sangat penting untuk dijadikan bahan ajar guna melestarikan dan menambah ilmu pengetahuan tentang seni dan budaya lokal setempat untuk mendukung pemahaman materi yang sedang dibahas dalam mata kuliah Introduction to Literature. Hal ini selaras dengan poin pertanyaan uraian yang yang dijelaskan secara kualitatif yang menyatakan bahwa sastra lokal, dalam hal ini seni dan budaya sangat penting untuk dipelajari guna membantu memahami teks yang ada. Adapun contoh-contoh yang disebutkan dalam soal uraian antara lain yaitu; guritan, tadut, berejung, andai-andai dan sanstra lisan lainnya. Sesuai dengan pendapat Prastowo (2011: 19) mutu pembelajaran menjadi rendah ketika pendidikan hanya terpaku pada bahan-bahan ajar konvensional tanpa ada kreativitas untuk mengembangkan bahan ajar tersebut secara inovatif. Dengan kata lain, mengembangkan bahan ajar menjadi suatu produk yang inovatif akan mendukung proses pencapaian tujuan pembelajaran. 
Temuan penelitian ini juga didukung oleh pendapat (Sutarno, 2008: p. 76) yang menyebutkan bahwa belajar dengan budaya, terjadi pada saat budaya diperkenalkan kepada siswa sebagai cara atau metode untuk mempelajari pokok bahasan tertentu. Belajar dengan budaya meliputi pemanfaatan beragam untuk perwujudan budaya. Dalam belajar dengan budaya, budaya dan perwujudannya menjadi media pembelajaran dalam proses belajar, menjadi konteks dari contoh-contoh tentang konsep atau prinsip dalam suatu mata pelajaran, serta menjadi konteks penerapan prinsip atau prosedur dalam suatu mata pelajaran.

Dari segi desain modul, hasil kuisioner menunjukan bahwa desain yang ada sudah menarik akan tetapi, isi bacaan sulit untuk dipahami. Kemudian, pada poin motivasi, hasil kuisioner memperlihatkan bahwa rata-rata mahasiswa memiliki motivasi sedang dalam belajar sastra akan tetapi, modul yang digunakan sudah memenuhi kebutuhan mereka. Hal ini dimungkinkan karena bahasa yang digunakan adalah bahasa asing, yang mungkin menjadi kendala kurang memahami isi teks yang digunakan. Berdasarkan pernyataan Irham dan Wiyani (2013: 266), faktor kesulitan internal dalam belajar meliputi; a) sikap siswa terhadap belajar, b) motivasi belajar siswa, c) konsentrasi belajar siswa, d) cara siswa mengolah bahan ajar, e) kemampuan siswa menyimpan perolehan hasil belajar, f) proses siswa dalam menggali hasil belajar yang tersimpan, g) kemampuan siswa untuk berprestasi dan unjuk bekerja, h) rasa percaya diri siswa, i) intelegansi dan keberhasilan siswa, j) kebiasaan belajar siswa, dan k) cita-cita siswa itu sendiri. Artinya, banyak faktor dapat mempengaruhi pemahaman siswa dalam belajar, diantaranya adalah motivasi dan pengolahan bahan ajar.

Pada respon terendah, hasil kuisioner menyatakan bahwa pemahaman sastra rata-rata mahasiswa adalah cukup, mereka mengangap mata kuliah Introduction to Literature penting bagi mereka akan tetapi, mereka mengalami beberapa kesulitan ketika harus mengembangkan keahlian mereka dalam menulis karya sastra. Selanjutnya, hasil kuisioner menyatakan bahwa para mahasiswa sulit memahami bahasa teks, mengapresiasi karya satra dalam teks dan tidak familiar dengan karya sastra yang disajikan. Kendala-kendala ini kemungkinan menjadi permasalahan bagi para mahasiswa dalam memahami isi bacaan sastra. Hal ini selaras dengan pernyataan Nurgiantoro (2010:422) yang menyebutkan bahwa:

Dibandingkan tiga kompetensi berbahasa yang lain, kompetensi menulis secara umum boleh dikatakan sulit dikuasai bahkan oleh penutur asli bahasa yang bersangkutan sekalipun. Hal ini disebabkan karena kompetensi menulis menghendaki penguasaan berbagai unsur kebahasaan dan unsur di luar bahasa itu sendiri yang akan menjadi karangan.

Dapat dikatakan bahwa diantara kompetensi-kompetensi yang ada, menulis memang dianggap sulit untuk dikuasai, hal ini karena diperlukannya unsur-unsur kebahasaan itu sendiri yang didikung oleh unsur ekternal lain yang saling terikat satu sama lain.

Dari hasil-hasil temuan di atas, dapat disimpulkan bahwa dari hasil kuisioner mahasiswa diperoleh informasi bahwa mahasiswa mengangap pengintegrasian budaya lokal ke dalam materi sastra sangat penting. Hal ini selaras dengan hasil temuan kuisioner dengan persentase 3 tertinggi yang menjelaskan bahwa rata-rata mahasiswa menyukai sastra dan menganggap pengintegrasian budaya lokal ke dalam materi sastra sangat penting untuk menambah latar belakang ilmu pengetahuan tentang materi yang ada dalam teks. Hal ini juga didukung oleh pernyataan Sternberg, Jarvin \& Reznitskaya (2008) dalam bukunya Teaching for Wisdom through History: Infusing Wise Thingking Skills in the School Curriculum yang menyatakan bahwa sekolah dapat membantu mengembangkan kearifan.

2. Hasil Wawancara Dosen 
Dari hasil wawancara dengan dosen yang disajikan secara kualitatif, diperoleh informasi bahwa dosen pengampuh mata kuliah sudah mengajar mata kuliah Introduction to Literature selama kurang lebih 14 tahun, adapun masalah-masalah yang dihadapi mahasiswa dalam belajar mata kuliah Introduction to Literature diantaranya adalah; kurang memahami istilah-istilah sastra, kurang familiar dengan karya sastra yang disajikan, sulit memahami teks karena dalam bahasa Inggris, sulit mengembangkan keahlian dalam menulis karya sastra dan memiliki motivasi belajar yang sedang akan tetapi, ada beberapa diantara mahasiswa yang sangat antusias dalam belajar namun demikian, rata-rata mahasiswa kurang paham terhadap isi dari bacaan yang disajikan. Problematika pembelajaran ini dapat berasal dari dua faktor, yaitu faktor internal yang meliputi sikap terhadap belajar, motivasi belajar, konsentrasi belajar, kebiasaan belajar dan juga faktor eksternal yang meliputi proses belajar yang didorong oleh motivasi intrinsik peserta didik. Proses belajar juga dapat terjadi, atau menjadi bertambah kuat, bila didorong oleh lingkungan peserta didik (Roinah, 2019).

Dari segi modul yang dipakai, modul yang digunakan sudah memadai secara isi, memiliki desain yang cukup menarik, memiliki tujuan pembelajaran yang jelas, memiliki lembar kerja atau lembar evaluasi, namun, dari segi ukuran perlu diperbesar dan lembar kerja perlu ditambah. Seperti yang dikatakan oleh Lestari (2013: 1). Bahan ajar adalah seperangkat sarana atau alat pembelajaran yang berisikan materi pembelajaran, metode, batasan-batasan, dan cara mengevaluasi yang didesain secara sistematis dan menarik dalam rangka mencapai tujuan yang diharapkan, yaitu mencapai kompetensi atau sub kompetensi dengan segala kompleksitasnya.

Dari kedua hasil instrument yang dilakukan dapat disimpulkan bahwa kemiripan hasil dari kuisioner mahasiswa dan wawancara dosen menunjukan bahwa masalah yang dihadapi dosen dan mahasiswa adalah sama diantaranya adalah mahasiswa memiliki motivasi sedang meskipun mereka menyukai sastra atau literature. Mereka juga mengalami kesulitan memahami bahasa teks, kurang memahami istilahistilah sastra, mengalami kesulitan dalam mengapresiasi karya sastra dan kurang memiliki skill dalam menulis teks sastra.

3. Hasil Validasi Ahli

Menurut hasil validasi ahli, dapat dikatakan bahwa dari 10 (sepuluh) aspek yang dinilai rata-rata yang diperoleh adalah 13,6 hal ini menunjukan bahwa hasil yang diperoleh sudah cukup baik atau memenuhi kriteria ketentuan umum sebuah bahan ajar. Adapun nilai tertinggi terdapat pada aspek materi kearifan lokal, hal ini kemungkinan besar dikarenakan materi yang disajikan sesuai dengan latar belakang mahasiswa serta membantu pemahaman mereka terhadap teks yang ada. Menurut Prastowo (2011: 17) bahan ajar yang baik adalah bahan ajar yang disusun harus sesuai dengan karakteristik siswa dan menampilkan sosok utuh dari kompetensi yang akan dikuasai oleh siswa dalam proses pembelajaran.

Nilai tertinggi berikutnya terdapat pada aspek huruf, ukuran huruf, dan pengetikan dengan poin 15 , hal ini kemungkinan dikarenakan aspek ini cukup membantu pembaca dalam memahami bacaan karena penggunaan huruf, ukuran huruf dan segi pengetikannya yang tepat, tidak terlalu kecil, ataupun terlalu besar. Kemudian, pada nilai tertinggi berikutnya terdapat pada aspek spasi, hal ini dapat diartikan bahwa spasi yang digunakan sesuai dengan yang diharapkan pembaca. Tidak terlalu rapat ataupun terlalu renggang.

Aspek-aspek lain seperti; desain sampul, tata letak, penyajian materi, instruksi pembelajaran, isi, bahasa dan latihan mendapat nilai 12-13. Hal ini dapat dikatakan bahwa secara keseluruhan, aspek-aspek yang dinilai oleh validator ahli sudah cukup 
memenuhi kebutuhan mahasiswa dari segi isi, bahasa, penyajian dan grafik. Menurut BSNP (2007), buku teks yang berkualitas wajib memenuhi empat unsur kelayakan, yaitu kelayakan isi, kelayakan penyajian, kelayakan kebahasaan dan kelayakan kegrafikaan.

4. Pengembangan

Pengembangan bahan ajar dilakukan berdasarkan analisa kebutuhan mahasiwa dan dosen dengan metode pengembangan model ADDIE. Setelah analisa kebutuhan ditemukan, langkah berikut adalah mendesain bahan ajar dengan mempertimbangkan kurikulum dan RPS yang digunakan. Kemudian dilakukan pengembangan sesuai dengan kebutuhan mahasiswa dan dosen. Setelah pengembangan dilakukan langkah terakhir adalah validasi ahli guna mengecek bahan ajar secara keseluruhan baik dari segi isi, penyajian, bahasa dan grafik. Selanjutnya, jika terdapat saran untuk perbaikan maka dilakukan perbaikan dan buku siap untuk dijadikan buku ajar sebagai referensi atau buku pendamping guna membantu mahasiswa mempelajari materi inti di kelas.

\section{PENUTUP}

Dilihat dari hasil kuisioner mahasiswa, wawancara dengan dosen pengampuh mata kuliah, hasil validasi ahli dan pengembangan yang dilakukan, dapat disimpulkan bahwa hasil pengembangan bahan ajar sudah memenuhi kebutuhan mahasiswa untuk membantu mereka lebih memahami buku teks yang digunakan di kelas. Bahan ajar tersebut dikembangkan kedalam 12 bab yang keseluruhan materinya berbasis kearifan lokal Besemah. Setelah melalui validasi ahli, dapat dikatakan bahwa bahan ajar hasil pengembangan sudah memenuhi kebutuhan mahasiswa dari segi substansi, penyajian, kebahasaan dan kegrafikan.

Karena penelitian ini hanya menggunakan kuisioner dan wawancara untuk menggali kebutuhan objek penelitian, disarankan bagi peneliti lain untuk mengkaji kebutuhan objek penelitian lebih dalam dengan menggunakan instrumen-instrumen penelitian lain sehingga informasi yang digali dapat menampung semua kebutuhan objek penelitian. Kemudian, disarankan kepada para peneliti untuk lebih kreatif lagi dalam mengembangkan bahan ajar agar mahasiswa terbantu dalam memahami teks utama yang digunakan.

\section{Ucapan Terima Kasih}

Saya menggucapkan terimah kasih dan apresiasi setinggi-tingginya kepada Kemenristek/BRIN atas pendanaan hibah penelitian yang saya peroleh. Ucapan terima kasih juga saya sampaikan kepada ketua STKIPM Muhammadiyah Pagaralam, Bapak Jonni, S.E., M.Si atas dukungannya dalam meraih kompetisi hibah ini. Ucapan terima kasih juga saya sampaikan kepada para unsur pimpinan dan teman sejawat STKIP Muhammadiyah Pagaralam yang telah membantu proses penelitian ini. Kepada para mahasiswa STKIP Muhammadiyah Pagaralam juga saya ucapkan terimah kasih atas partisipasi, kontribusi dan kerjasamanya dalam penelitian ini. 


\section{Daftar Rujukan}

Bao, D 2016. "Improvements in Today's ELT Material Development" in Azarnaoose Maryam et.al (Eds). Issues in Material Development. Sense Publisher: Rotterdam.

Barokati, N., dan Annas, F. 2013. Pengembangan Pembelajaran Berbasis Blended Learning pada Mata Kuliah Pemrograman Komputer (Studi Kasus: UNISDA Lamongan). Jurnal Sistem Informasi Vol. 4 (5), 352-359.

BSNP. 2007. Kurikulum Tingkat Satuan Pendidikan. Jakarta: BSNP.

Dick, W and L. Carey, J. O. Carey. 2005. The systematic Design of Instruction. New York: Logman.

Erdem, M. 2016. Literature in English Language Teaching. European Journal of Language and Literature Studies, 2(1), 157-162. doi: 10.26417/ejls.v4i1.p157-162.

Irham, M. \& Wiyani, N. A. 2013. Psikologi Pendidikan: Teori dan aplikasi dalam proses pembelajaran. Jogjakarta: Ar-ruzz Media.

Lestari, I. 2013. Pengembangan Bahan Ajar Berbasis Kompetensi. Padang: Akademia Permata.

Mckay, S. L. 2003. Toward an Appropriate EIL Pedagogy: Reexamining ELT assumptions.

International Journal of Applied Linguistic, 13(1).

(http://people.upr.br/ clarissa/pdf s/EILpedagogy-Mckay).

Noviarni. 2014. Perencanaan Pembelajaran Matematika dan Aplikasinya Menuju Guru yang Kreatif dan Inovatif. Pekanbaru: Banteng Media.

Prastowo, A. (2011). Panduan Kreatif Membuat Bahan Ajar Inovatif. Yogyakarta: Diva Press.

Prastowo, A. (2014). Panduan Kreatif Membuat Bahan Ajar Inovatif. Yogyakarta: Diva Press.

Roinah. 2019. Problematika Dalam Pembelajaran Bahasa Inggris di Stain Bengkalis QUALITY Vol. 7, (1), 2019: 153-166

Sugiyono. 2015. Metodologi Penelitian Pendidikan. Bandung: Alfabeta.

Sutarno. 2008. Pendidikan Multikultural. Jakarta: Direktorat Jendral Pendidikan Tinggi Departemen Pendidikan Nasional.

Sternberg, R., Jarvin, L., Reznitskaya, A. 2008. Teaching for Wisdom through History: Infusing Wise Thinking Skills in School Curriculum. Retrived from https://www.researchgate.net/publication/225831443 Teaching for Wisdo $\mathrm{m}$ Through HistoryInfusing Wise Thinking Skills in the School Curricul um/citation/download

Tegeh, I.M. \& Kirna, I.M. 2013. Pengembangan Bahan Ajar Metode Penelitian Pendidikan dengan ADDIE Model. Jurnal Ika Vol. 11(1), 12- 26.

Tomlinson, B. (2012). Introduction: Principles and Procedures of Materials Development. (http://assets.cambridge.org.7628 54-excerpt. Pdf). 